\title{
ANALISIS KUALITAS UDARA DENGAN INDEKS STANDAR PENCEMAR UDARA (ISPU) DAN SEBARAN KADAR POLUTANNYA DI PROVINSI DKI JAKARTA
}

\section{AIR QUALITY ANALYSIS WITH AIR POLLUTION STANDARD INDEX (ISPU) AND THE DISTRIBUTION OF POLLUTANT LEVELS IN DKI JAKARTA PROVINCE}

\author{
Putri Imas Agista ${ }^{1}$, Ninin Gusdini ${ }^{2}$, Maya Dewi Dyah Maharani ${ }^{3}$ \\ ${ }^{1}$ Program Studi Teknik Lingkungan, Fakultas Teknik, Universitas Sahid Jakarta, Jl. Prof. Dr. Soepomo, SH \\ No.84 Tebet Jakarta, Email : putriagista17@gmail.com \\ ${ }^{2}$ Program Studi Teknik Lingkungan, Fakultas Teknik, Universitas Sahid Jakarta, Jl. Prof. Dr. Soepomo, SH \\ No.84 Tebet Jakarta, Email : ninin_gusdini@usahid.ac.id \\ ${ }^{3}$ Program Studi Teknik Lingkungan, Fakultas Teknik, Universitas Sahid Jakarta, Jl. Prof. Dr. Soepomo, SH \\ No.84 Tebet Jakarta, Email : maya@usahid.ac.id
}

\begin{abstract}
ABSTRAK
Provinsi DKI Jakarta merupakan ibu kota Indonesia yang memiliki lima kota besar yaitu Jakarta Pusat, Jakarta Utara, Jakarta Selatan, Jakarta Timur dan Jakarta Barat. Sebagai kota yang sedang berkembang Provinsi DKI Jakarta turut menyumbangkan emisi udara yang menyebabkan menurunnya kualitas udara melalui kegiatan penduduk, kegiatan perindustrian dan transportasi. Oleh karena itu Dinas Lingkungan Hidup (DLH) DKI Jakarta memantau kadar pencemar udara primer yaitu NO2 (Nitrogen Dioksida), SO2 (Sulfur Dioksida), O3 (Ozon), CO (Karbon Monoksida) dan PM10 (Partikulat). Analisis dilakukan menggunakan Indeks Standar Pencemar Udara (ISPU) di lima kota besar di DKI Jakarta untuk mengetahui kualitas udara selama lima tahun terakhir tahun 2014 hingga tahun 2018. Kadar pencemar udara parameter NO2, SO2 dan CO di DKI Jakarta tahun 2014-2018 masih di bawah Nilai Ambang Batas (NAB) berurutan 400,00 $\mu \mathrm{g} / \mathrm{m} 3,365,00 \mu \mathrm{g} / \mathrm{m} 3$ dan $30.000 \mu \mathrm{g} / \mathrm{m} 3$, sedangkan untuk parameter O3 dan PM10 di DKI Jakarta rata-rata kadar maksimum 249,00-456,10 $\mu \mathrm{g} / \mathrm{m} 3$ dan 158,00-206,00 $\mu \mathrm{g} / \mathrm{m} 3$ tahun 2014-2018 melewati NAB yaitu berurutan $235.00 \mu \mathrm{g} / \mathrm{m} 3$ dan $150,00 \mu \mathrm{g} / \mathrm{m} 3$. Sesuai kadarnya yang tinggi untuk parameter O3 dan PM10 menghasilkan kualitas udara yang buruk, untuk kota Jakarta Utara, Jakarta Selatan dan Jakarta Barat tahun 2018 menjadi tahun dengan kualitas udara terburuk dikarenakan perkembangan industri, sedangkan Jakarta Pusat tahun 2017 kualitas udara terburuk dan Jakarta Timur tahun 2014. Dilihat dari pola sebaran polutannya menggunakan software Surfer 11, khusus untuk parameter pencemar udara PM10 mengalami perbaikan karena meningkatnya zonasi daerah kadar rendah di DKI Jakarta dikarenakan menurunnya jumlah kendaraan dan meningkatnya teknologi transportasi yang ramah lingkungan seperti mengganti transjakarta menjadi standar mesin Uni-Eropa IV-V dari Uni-Eropa II, ISS (Idling Stop System) pada kendaraan motor.
\end{abstract}

Kata Kunci : ISPU, Surfer 11, Provinsi DKI Jakarta

\begin{abstract}
DKI Jakarta Province is the capital city of Indonesia that have 5 major cities which are Central Jakarta, North Jakarta, South Jakarta, East Jakarta, and West Jakarta. As one of the developing city, DKI Jakarta Province have a major contributes of air emission that made the air quality decrease through domestic, industrial, and also transportation. Therefore, Environmental Institution of DKI Jakarta have been monitoring primary air pollutans level represent by NO2 (Nitrogen dioxide), SO2 (Sulfur dioxide), O3 (ozone), CO (Carbon monoxide) and PM1O (Particulate). All parameters will be analysis by Air Pollutant Standard Index (APSI) in 5 major cities of DKI Jakarta Province to know the air quality for the past 5 years starting from 2014 to 2018. Air pollutants level of parameter NO2, SO2, and CO in
\end{abstract}


DKI Jakarta from 2014 to 2018 were below the threshold value which are 400,00 $\mu \mathrm{g} / \mathrm{m} 3,365,00 \mu \mathrm{g} / \mathrm{m} 3$ and $30.000 \mu \mathrm{g} / \mathrm{m} 3$ meanwhile for $O 3$ and PM10 exceed the threshold value which are $235.00 \mu \mathrm{g} / \mathrm{m} 3$ and $150,00 \mu \mathrm{g} / \mathrm{m} 3$. The high level of O3 and PM1O causing poor air quality in North Jakarta, South Jakarta, and West Jakarta in 2018 become the worst year of air quality causing by industrial development, meanwhile Central Jakarta in 2017 become the worst air quality and East Jakarta in 2014. Based on pollutants distribution analysis using software surfer 11, PM10 level has been decreased due to a decrease in number of vehicles and improvement of technology that more eco-friendly such as substitute standard machine of transjakarta from Uni-Eropa II to Uni-Eropa IV-V and also using ISS (Idling Stop System) on motorcycle.

Keyword: APSI, DKI Jakarta Province, Surfer 11

\section{Pendahuluan}

Udara merupakan sumber yang tidak terbatas dan sumber daya milik bersama, yang mempengaruhi kehidupan manusia serta makhluk hidup lainnya. Pemeliharaan terhadap fungsi udara harus dilakukan demi menjaga kesehatan dan kesejahteraan manusia serta melindungi makhluk hidup lainnya. Pencemaran udara diartikan dengan turunnya kualitas udara sehingga udara mengalami penurunan mutu dalam penggunaannya dan akhirnya tidak dapat dipergunakan lagi sebagai mana mestinya sesuai dengan fungsinya menurut Peraturan Pemerintah (PP) No. 41 Tahun 1999. Kecenderungan menurunnya kualitas udara dapat diakibatkan oleh faktor alam dan manusia. Faktor alam yang dapat mencemari udara salah satunya adalah aktivitas vulkanik gunung. Sedangkan Faktor manusia yang paling dominan adalah aktivitas transportasi dan perindustrian seiring dengan pertumbuhan penduduk.

Provinsi DKI Jakarta menjadi ibu kota yang berpenduduk padat, semakin padat penduduk semakin banyak dan bervariasi kegiatan manusia. Menurut Badan Pusat Statistik (BPS) DKI Jakarta terjadi kenaikan pada produksi industri yang dapat menimbulkan emisi seperti industri tekstil sebesar $10.13 \%$, industri kelistrikan $9,07 \%$, industri logam 7,54\% dan industri kendaraan bermotor 1,47\% pada tahun 2018 terhadap tahun 2017. Terdapat lima kota besar yang terbagi di DKI Jakarta, yaitu Jakarta Utara, Jakarta Selatan, Jakarta Barat, Jakarta Timur dan Jakarta Pusat. Pada kelima kota di DKI Jakarta tersebut tersebar berbagai macam industri yang dapat menghasilkan emisi. Melalui pertumbuhan penduduk di kelima kota tersebut juga dapat mempengaruhi polusi dari kendaraan yang dapat menyumbang sebagai sumber pencemar udara tercatat dalam Jakarta Dalam Angka 2018 terjadi peningkatan pada jumlah kendaraan sebesar 6\% - 9\% per tahunnya. Tercatat berdasarkan BPS DKI Jakarta laju pertumbuhan penduduk di Jakarta Selatan 0,91\%, Jakarta Timur 0,83\%, Jakarta Pusat 0,39\%, Jakarta Barat 1,28\% dan Jakarta Utara 0,95\%, dengan jumlah total kendaraan pribadi sebanyak 18006404 yang terdaftar pada tahun 2017. Oleh karena itu Dinas Lingkungan Hidup (DLH) DKI Jakarta membuat stasiun pemantauan kualitas udara di lima kota besar di DKI Jakarta untuk memantau polusi utama udara seperti NO2 (Nitrogen Dioksida), SO2 (Sulfur Dioksida), O3 (Ozon), CO (Karbon Monoksida) dan PM10 (Partikulat). Berdasarkan sumber polutan yang semakin meningkat di daerah DKI Jakarta, oleh karena analisis kualitas udara di DKI Jakarta perlu dilakukan.

Penelitian ini dilakukan untuk menganalisis kualitas udara meliputi kadar polutan utama pencemar udara NO2 (Nitrogen Dioksida), SO2 (Sulfur Dioksida), O3 (Ozon), CO (Karbon Monoksida) dan PM10 (Partikulat), kategori kualitas udara yang di hitung berdasarkan Indeks Standar Pencemar Udara (ISPU) dan sebaran kadar polutannya yang diwakilkan oleh lima kota besar di Provinsi DKI Jakarta yaitu Jakarta Utara, Jakarta Selatan, Jakarta Timur, Jakarta Barat dan Jakarta Pusat. 


\section{Metodologi Penelitian}

Penelitian ini adalah penelitian noneksperimen yang termasuk dalam deskriptif kuantitatif. Penelitian dilakukan untuk mengetahui kualitas udara di DKI Jakarta yang diwakilkan lima kota besar yaitu Jakarta Utara, Jakarta Selatan, Jakarta Timur, Jakarta Barat dan Jakarta Pusat. Penelitian atau pengolahan data penelitian dilakukan pada bulan Januari hingga Maret 2019. Penelitian menggunakan data sekunder yang diperoleh dari Kementrian Lingkungan Hidup dan Kehutanan, Badan Pusat Statistik, Dinas Lingkungan Hidup (DLH) DKI Jakarta dan Lembaga atau Instansi lainnya. Data diperoleh dari stasiun pemantauan kualitas udara ambien di DKI Jakarta pada tahun 2014-2018 yang diwakilkan lima kota besar yaitu Jakarta Utara, Jakarta Selatan, Jakarta Timur, Jakarta Barat dan Jakarta Pusat.

\section{Hasil dan Pembahasan}

\subsection{Kadar Polutan Pencemar Udara Primer di DKI Jakarta Tahun 2014-2018}

Stasiun pemantauan kualitas udara yang di lakukan Dinas Lingkungan Hidup DKI Jakarta di lokasikan di lima kota besar yitu Jakarta Pusat, Jakarta Utara, Jakarta Selatan, Jakarta Timur dan Jakarta Barat.

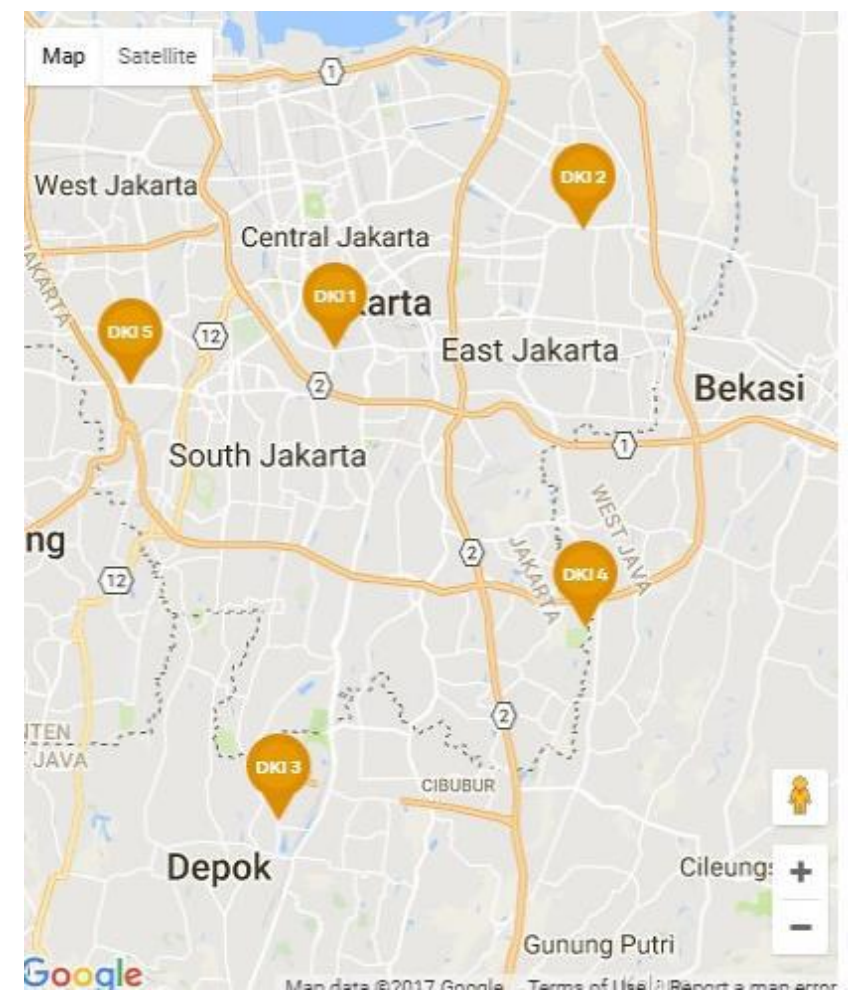

Gambar 1. Titik Lokasi Stasiun Pemantauan Kualitas Udara di Provinsi DKI Jakarta

Sumber: Dinas Lingkungan Hidup DKI Jakarta

Keterangan Lokasi :

DKI 1 (Jakarta Pusat)

Lokasi : Dekat kantor Pos Polisi BundaranHI

Koordinat : -6.196271,106.822921

DKI 2 (Jakarta Utara)

Lokasi : Jl. Nias Raya, Kantor Kelurahan Nias Kelapa Gading

Koordinat : -6.154454,106.910845 
DKI 3 (Jakarta Selatan)

Lokasi : Taman Pendidikan Dinas Pertamanan, Jagakarsa

Koordinat : $-6.356317,106.804713$

DKI 4 (Jakarta Timur)

Lokasi : Jl. Raya Pondok Gede RT. 4 RW. 12 Halaman Parkir Monumen Pancasila Sakti

Koordinat : $-6.290345,106.908610$

DKI 5 (Jakarta Barat)

Lokasi : Taman Perumahan Kebon Jeruk Blok J6, Kebon Jeruk

Koordinat : $-6.209225,106.753437$

Tabel 1. Hasil Maksimum dan Minimum Kadar Polutan di Provinsi DKI Jakarta Tahun 2014-2018

\begin{tabular}{|c|c|c|c|c|c|c|c|c|c|c|}
\hline \multirow[b]{2}{*}{ Kota } & \multicolumn{10}{|c|}{ Maksimum } \\
\hline & $\begin{array}{l}\text { PM10 } \\
(\mu \mathrm{g} / \mathrm{m} 3)\end{array}$ & Tahun & $\begin{array}{c}\mathrm{SO} 2 \\
(\mu \mathrm{g} / \mathrm{m} 3)\end{array}$ & Tahun & $\begin{array}{c}\mathrm{CO} \\
(\mu \mathrm{g} / \mathrm{m} 3)\end{array}$ & Tahun & $\begin{array}{c}\mathrm{O} 3 \\
(\mu \mathrm{g} / \mathrm{m} 3)\end{array}$ & Tahun & $\begin{array}{c}\mathrm{NO} 2 \\
(\mu \mathrm{g} / \mathrm{m} 3)\end{array}$ & Tahun \\
\hline $\begin{array}{c}\text { Jakarta } \\
\text { Pusat }\end{array}$ & 158 & 2016 & 76,8 & 2016 & 9000 & 2014 & 317,5 & 2017 & 220,35 & 2015 \\
\hline $\begin{array}{c}\text { Jakarta } \\
\text { Utara }\end{array}$ & 182 & 2014 & 53,35 & 2017 & 6000 & 2014 & 456 & 2018 & 220,35 & 2015 \\
\hline $\begin{array}{l}\text { Jakarta } \\
\text { Selatan }\end{array}$ & 186 & 2017 & 92,8 & 2018 & 7200 & 2015 & 368,5 & 2018 & 169,5 & 2015 \\
\hline $\begin{array}{l}\text { Jakarta } \\
\text { Timur }\end{array}$ & 206 & 2016 & 115,2 & 2018 & 7200 & 2016 & 249 & 2014 & 237,3 & 2015 \\
\hline $\begin{array}{c}\text { Jakarta } \\
\text { Barat }\end{array}$ & 178 & 2015 & 80 & 2018 & 11900 & 2014 & 456,1 & 2018 & 355,9 & 2015 \\
\hline \multirow[b]{2}{*}{ Kota } & \multicolumn{10}{|c|}{ Maksimum } \\
\hline & $\begin{array}{l}\text { PM10 } \\
(\mu \mathrm{g} / \mathrm{m} 3)\end{array}$ & Tahun & $\begin{array}{c}\mathrm{SO} 2 \\
(\mu \mathrm{g} / \mathrm{m} 3)\end{array}$ & Tahun & $\begin{array}{c}\mathrm{CO} \\
(\mu \mathrm{g} / \mathrm{m} 3)\end{array}$ & Tahun & $\begin{array}{c}\mathrm{O} 3 \\
(\mu \mathrm{g} / \mathrm{m} 3)\end{array}$ & Tahun & $\begin{array}{c}\mathrm{NO} 2 \\
(\mu \mathrm{g} / \mathrm{m} 3)\end{array}$ & Tahun \\
\hline $\begin{array}{c}\text { Jakarta } \\
\text { Pusat }\end{array}$ & 4 & 2018 & 1,6 & 2015 & 400 & 2018 & 9,6 & 2018 & 5,65 & $\begin{array}{c}2015 \& \\
2016\end{array}$ \\
\hline $\begin{array}{c}\text { Jakarta } \\
\text { Utara }\end{array}$ & 20 & 2017 & 6 & 2015 & 300 & 2018 & 26,4 & 2014 & 5,65 & 2017 \\
\hline $\begin{array}{l}\text { Jakarta } \\
\text { Selatan }\end{array}$ & 2 & 2017 & 1,6 & 2014 & 200 & 2018 & 9,6 & 2015 & 5,65 & 2017 \\
\hline $\begin{array}{l}\text { Jakarta } \\
\text { Timur }\end{array}$ & 7 & 2016 & 3,2 & 2015 & 100 & $\begin{array}{c}2015 \& \\
2017\end{array}$ & 21,6 & 2014 & 5,65 & 2017 \\
\hline $\begin{array}{c}\text { Jakarta } \\
\text { Barat }\end{array}$ & 2 & 2016 & 1,6 & 2014 & 100 & 2017 & 7,2 & $\begin{array}{c}2014 \& \\
2015\end{array}$ & 5,65 & $\begin{array}{c}2016 \& \\
2018\end{array}$ \\
\hline
\end{tabular}

Dari hasil pemantauan stasiun kualitas lingkungan bahwa kadar polutan PM10 maksimum berada pada range 158,00-206,00 $\mu \mathrm{g} / \mathrm{m}^{3}$ yang melewati NAB sebesar $150,00 \mu \mathrm{g} / \mathrm{m}^{3}$, sedangkan kadar minimum berada pada range 2,00-20,00 $\mu \mathrm{g} / \mathrm{m}^{3}$ di DKI Jakarta. Untuk kadar polutan SO2 kadar maksimum berada pada range 53,35-115,20 $\mu \mathrm{g} / \mathrm{m}^{3}$ aman di bawah NAB sebesar $365,00 \mu \mathrm{g} / \mathrm{m}^{3}$, sedangkan kadar minimum berada pada range $1,00-6,00 \mu \mathrm{g} / \mathrm{m}^{3}$ di DKI Jakarta. Pada polutan CO kadar maksimum berada pada range $7200-11900 \mu \mathrm{g} / \mathrm{m}^{3}$ aman di bawah NAB sebesar $30.000 \mu \mathrm{g} / \mathrm{m}^{3}$, sedangkan kadar minimum pada range $100-400 \mu \mathrm{g} / \mathrm{m}^{3}$ di 
DKI Jakarta. Kadar polutan O3 yang diukur menghasilkan kadar maksimum pada range 249,00$456,10 \mu \mathrm{g} / \mathrm{m}^{3}$ yang melewati NAB sebesar $235,00 \mu \mathrm{g} / \mathrm{m}^{3}$, sedangkan kadar minimum pada range 7,20-26,40 $\mu \mathrm{g} / \mathrm{m}^{3}$ di DKI Jakarta. Pada polutan NO2 yang diukur menghasilkan kadar tertinggi di range $169,50-355,90 \mu \mathrm{g} / \mathrm{m}^{3}$ aman di bawah NAB sebesar 400,00 $\mu \mathrm{g} / \mathrm{m}^{3}$, sedangkan untuk kadar minimumnya pada $5,65 \mu \mathrm{g} / \mathrm{m}^{3}$ di DKI Jakarta

\subsection{Kategori Kualitas Udara Menggunakan Indeks Standar Pencemaran Udara (ISPU)}

Penentuan kategori ISPU, terlebih dahulu dilakukan perhitungan nilai ISPU menggunakan kadar polutan yang di dapat dari DLH dihitung sesuai KEPBAPEDAL No. 107 Tahun 1997 yaitu :

$$
\mathrm{I}=\frac{\mathrm{Ia}-\mathrm{Ib}}{\mathrm{Xa}-\mathrm{Xb}}(X x-X b)+I b
$$

Keterangan:

$\mathrm{I}=$ ISPU terhitung (nilai ISPU)

$\mathrm{Ia}=$ ISPU batas atas

$\mathrm{Ib}=$ ISPU batas bawah

$\mathrm{Xa}=$ Ambien batas atas

$\mathrm{Xb}=$ Ambien batas bawah

$\mathrm{Xx}=$ Kadar ambien nyata hasil pengukuran

Tabel 2. Kualitas Udara Kategori ISPU di Provinsi DKI Jakarta Tahun 2014-2018

\begin{tabular}{lcccccc}
\hline \multicolumn{7}{c}{ Tahun 2014 } \\
\hline KATEGORI & DKI1 & DKI2 & DKI3 & DKI4 & DKI5 & JUMLAH \\
\hline BAIK & 77 & 56 & 155 & 42 & 63 & 393 \\
SEDANG & 276 & 269 & 176 & 301 & 240 & 1262 \\
TIDAK SEHAT & 5 & 30 & 20 & 19 & 54 & 128 \\
SANGAT TIDAK SEHAT & 0 & 0 & 0 & 3 & 5 & 8 \\
BERBAHAYA & 0 & 0 & 0 & 0 & 0 & 0 \\
TIDAK ADA DATA & 7 & 10 & 14 & 0 & 3 & 34 \\
\hline
\end{tabular}

\begin{tabular}{lcccccc}
\hline \multicolumn{7}{c}{ Tahun 2015 } \\
\hline KATEGORI & DKI1 & DKI2 & DKI3 & DKI4 & DKI5 & JUMLAH \\
\hline BAIK & 74 & 85 & 86 & 62 & 106 & 413 \\
SEDANG & 286 & 259 & 245 & 258 & 248 & 1296 \\
TIDAK SEHAT & 0 & 15 & 33 & 25 & 7 & 80 \\
SANGAT TIDAK SEHAT & 0 & 0 & 0 & 0 & 0 & 0 \\
BERBAHAYA & 0 & 0 & 0 & 0 & 0 & 0 \\
TIDAK ADA DATA & 5 & 6 & 1 & 20 & 4 & 36 \\
& \multicolumn{7}{c}{ Tahun 2016 } & & & \\
\hline KATEGORI & DKI1 & DKI2 & DKI3 & DKI4 & DKI5 & JUMLAH \\
\hline BAIK & 114 & 75 & 59 & 69 & 62 & 379 \\
SEDANG & 245 & 241 & 242 & 283 & 247 & 1258 \\
TIDAK SEHAT & 2 & 49 & 47 & 14 & 43 & 155 \\
\hline
\end{tabular}




\begin{tabular}{|c|c|c|c|c|c|c|}
\hline \multicolumn{7}{|c|}{ Tahun 2016} \\
\hline KATEGORI & DKI1 & DKI2 & DKI3 & DKI4 & DKI5 & JUMLAH \\
\hline SANGAT TIDAK SEHAT & 0 & 1 & 0 & 0 & 0 & 1 \\
\hline BERBAHAYA & 0 & 0 & 0 & 0 & 0 & 0 \\
\hline TIDAK ADA DATA & 5 & 0 & 18 & 0 & 14 & 37 \\
\hline \multicolumn{7}{|c|}{ Tahun 2017} \\
\hline KATEGORI & DKI1 & DKI2 & DKI3 & DKI4 & DKI5 & JUMLAH \\
\hline BAIK & 117 & 83 & 82 & 78 & 116 & 476 \\
\hline SEDANG & 208 & 236 & 208 & 263 & 206 & 1121 \\
\hline TIDAK SEHAT & 28 & 42 & 64 & 21 & 43 & 198 \\
\hline SANGAT TIDAK SEHAT & 0 & 0 & 0 & 0 & 0 & 0 \\
\hline BERBAHAYA & 0 & 0 & 0 & 0 & 0 & 0 \\
\hline TIDAK ADA DATA & 12 & 4 & 11 & 3 & 0 & 30 \\
\hline \multicolumn{7}{|c|}{ Tahun 2018} \\
\hline KATEGORI & DKI1 & DKI2 & DKI3 & DKI4 & DKI5 & JUMLAH \\
\hline BAIK & 167 & 61 & 48 & 56 & 38 & 370 \\
\hline SEDANG & 180 & 174 & 222 & 293 & 142 & 1011 \\
\hline TIDAK SEHAT & 6 & 117 & 81 & 11 & 166 & 381 \\
\hline SANGAT TIDAK SEHAT & 0 & 11 & 0 & 0 & 19 & 30 \\
\hline BERBAHAYA & 0 & 0 & 0 & 0 & 0 & 0 \\
\hline TIDAK ADA DATA & 12 & 2 & 14 & 5 & 0 & 33 \\
\hline TOTAL HARI & 365 & 365 & 365 & 365 & 365 & 1825 \\
\hline
\end{tabular}

Kualitas udara di DKI Jakarta tahun 2014-2018, di dapatkan bahwa tahun 2018 merupakan tahun terburuk dari lima tahun terakhir. Tercatat bahwa sebanyak 381 hari tidak sehat dan sebanyak 30 hari sangat tidak sehat dari total pengukuran di lima kota di DKI Jakarta. Sedangkan tahun tersehat terdapat pada tahun 2015 dengan 80 hari tidak sehat dan nol hari kategori sangat tidak sehat. Dilihat dari data kategori Kota Jakarta Utara disebut sebagai kota yang paling tercemar di bandingkan tiga kota lainnya.

Tabel 3. Jumlah Inustri di Kota Jakarta Utara Tahun 2015-2018

\begin{tabular}{ccc}
\hline Tahun & Jumlah Industri & Bidang Industri \\
\hline 2015 & 4 & Suku cadang kendaraan \& pembangkitan listrik \\
2016 & 22 & Kendaraan pembangkit listrik \& rumah sakit \\
2017 & 40 & Kendaraan, pembangkit listrik, baja besi \& rumah sakit \\
2018 & 50 & Kendaraan, pembangkit listrik, baja besi \& rumah sakit \\
\hline
\end{tabular}

Dilihat dari Tabel 3. bahwa Kota Jakarta Utara mengalami peningkatan selama empat tahun terakir, pada tahun 2015 jumlah industri empat dan hanya ada dua bidang maka tahun 2015 menjadi tahun terbaik kualitas udaranya. Namun pada tahun 2018 total industri mencapai 50 perusahaan dan terbagi di empat bidang industri yang menghasilkan emisi ke udara dalam 
prosesnya. Maka tahun 2018 menjadi tahun yang paling buruk dibandingkan dengan empat tahun lainnya.

\subsection{Pola Sebaran Kadar Polutan PM10 di Provinsi DKI Jakarta Tahun 2014-2018}

Pengambaran sebaran polutan PM10 di udara ambien menggunakan software Surfer 11, dengan menggunakan asumsi dari garis kontur.

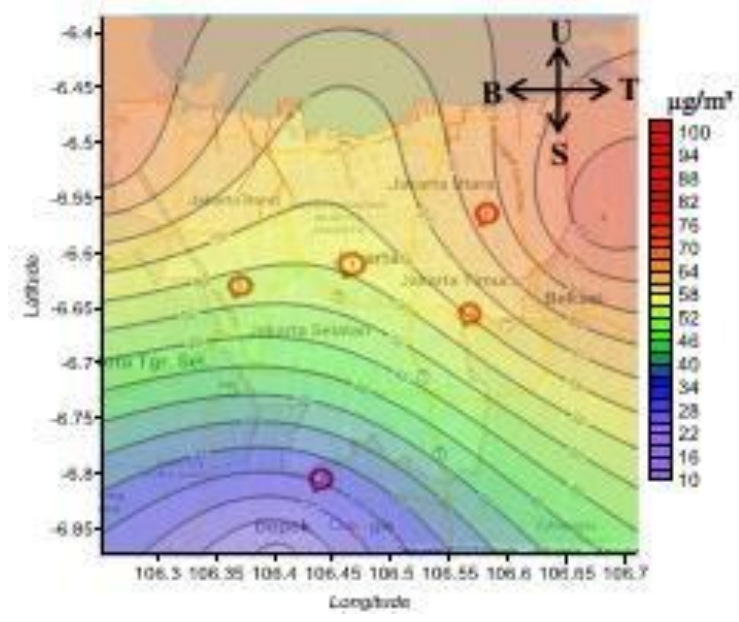

Gambar 2. Pola Sebaran PM10 di DKI Jakarta Tahun 2014

Daerah yang memiliki pola sebaran polutan PM10 tertinggi tahun 2014 adalah dari stasiun pemantauan kualitas udara DKI 4 ke DKI 2 dengan kisaran konsentrasi 70,00 $\mu \mathrm{g} / \mathrm{m}^{3}$ dan ke arah utara DKI 5 dan DKI 1. Sedangkan daerah sebaran yang memiliki sebaran polutan dengan kadar rendah adalah DKI 3 di Kota Jakarta Selatan memiliki kisaran kadar $<30,00$ $\mu \mathrm{g} / \mathrm{m}^{3}$.

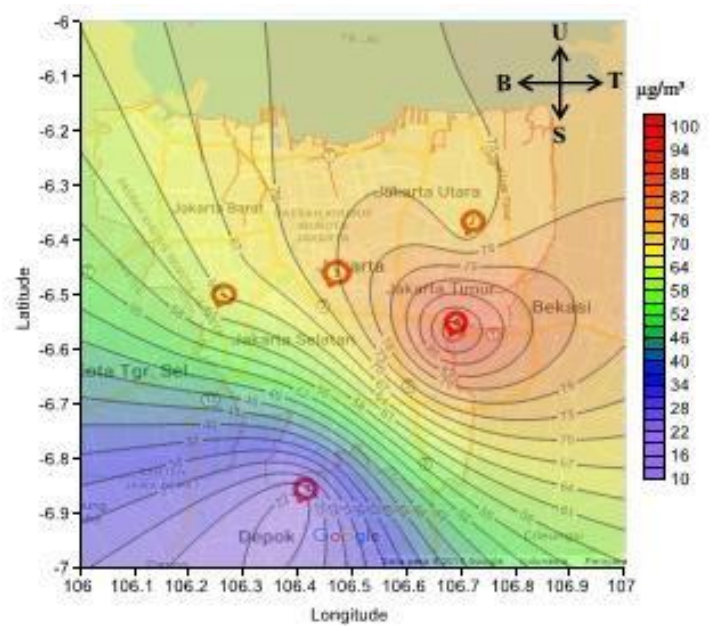

Gambar 3. Pola Sebaran PM10 di DKI Jakarta Tahun 2015

Daerah yang memiliki pola sebaran polutan $\mathrm{PM}_{10}$ tertinggi tahun 2015 adalah dari stasiun pemantauan kualitas udara DKI 4 menyebar ke DKI 2 dan DKI 1 dengan kisaran konsentrasi > $70,00 \mu \mathrm{g} / \mathrm{m}^{3}$. Sedangkan daerah sebaran yang memiliki sebaran polutan dengan kadar rendah adalah DKI 3 di Kota Jakarta Selatan memiliki kisaran kadar $<30,00 \mu \mathrm{g} / \mathrm{m}^{3}$. 


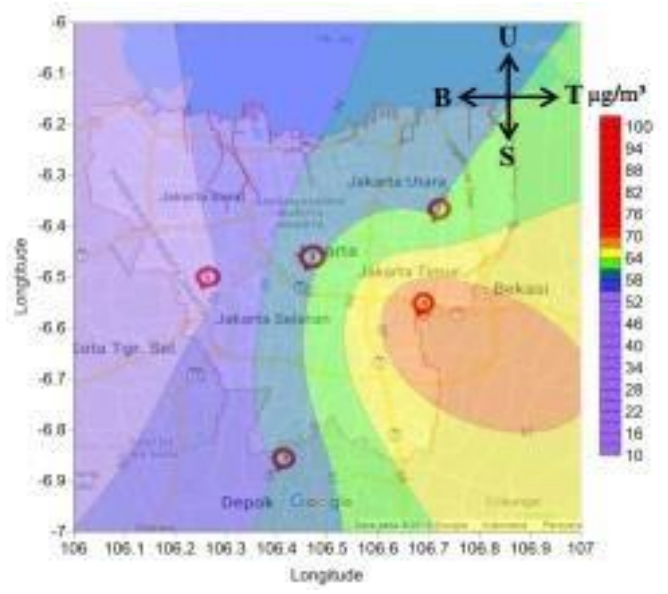

Gambar 4. Pola Sebaran $\mathrm{PM}_{10}$ di DKI Jakarta Tahun 2016

Daerah yang memiliki pola sebaran polutan $\mathrm{PM}_{10}$ tertinggi tahun 2016 adalah dari stasiun pemantauan kualitas udara DKI 4 menyebar ke daerah Bekasi dengan kisaran konsentrasi > $65,00-70,00 \mu \mathrm{g} / \mathrm{m}^{3}$. Sedangkan daerah sebaran yang memiliki sebaran polutan dengan kadar rendah adalah DKI 2 menyebar ke DKI 5 di Kota Jakarta Barat memiliki kisaran kadar < 40,00 $\mu \mathrm{g} / \mathrm{m}^{3}$.

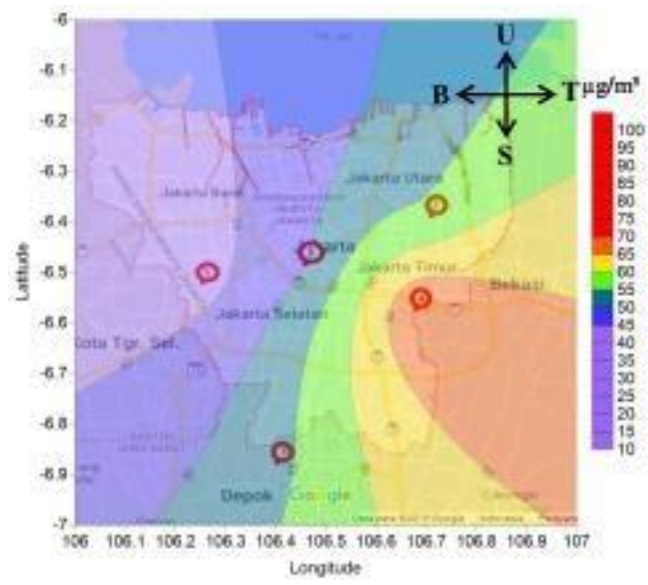

Gambar 5. Pola Sebaran $\mathrm{PM}_{10}$ di DKI Jakarta Tahun 2017

Daerah yang memiliki pola sebaran polutan $\mathrm{PM}_{10}$ tertinggi tahun 2017 sama seperti tahun 2016 dari stasiun pemantauan kualitas udara DKI 4 menyebar ke daerah Bekasi dengan kisaran konsentrasi $>65,00-70,00 \mu \mathrm{g} / \mathrm{m}^{3}$. Sedangkan daerah sebaran yang memiliki sebaran polutan dengan kadar rendah adalah DKI 2 menyebar ke DKI 5 di Kota Jakarta Barat memiliki kisaran kadar $<40,00 \mu \mathrm{g} / \mathrm{m}^{3}$.

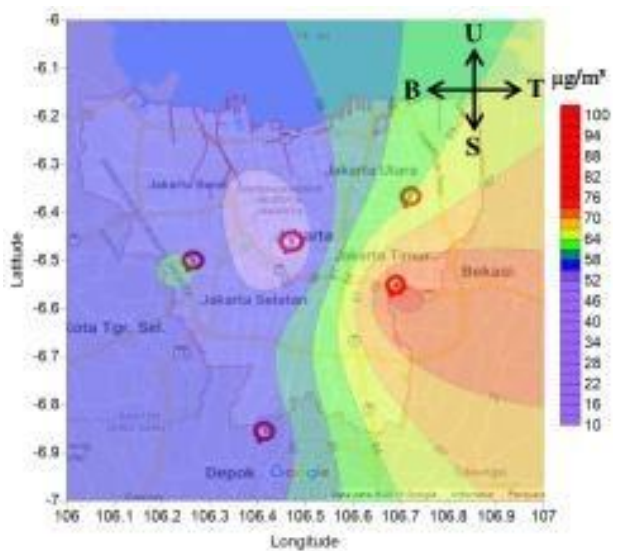

Gambar 6. Pola Sebaran PM10 di DKI Jakarta Tahun 2018 
Daerah yang memiliki pola sebaran polutan $\mathrm{PM}_{10}$ tertinggi tahun 2018 hampir sama seperti tahun 2016 dan 2017 dari stasiun pemantauan kualitas udara DKI 4 menyebar ke daerah Bekasi dengan kisaran konsentrasi $>70,00 \mu \mathrm{g} / \mathrm{m}^{3}$. Sedangkan daerah sebaran yang memiliki sebaran polutan dengan kadar rendah adalah DKI 2 menyebar ke DKI 1 dan DKI 3 di Kota Jakarta Barat memiliki kisaran kadar $<40,00 \mu \mathrm{g} / \mathrm{m}^{3}$ namun DKI 5 memiliki kadar yang sedang sekitar $60,00 \mu \mathrm{g} / \mathrm{m}^{3}$.

Dari pola sebaran polutan PM $_{10}$ yang telah di gambarkan di DKI Jakarta tahun 2014-2018 terlihat bahwa daerah sebaran yang memiliki kadar $\mathrm{PM}_{10}$ tinggi adalah stasiun pemantauan DKI 4 di Kota Jakarta Timur. Sedangkan sebaran polutan $\mathrm{PM}_{10}$ yang paling rendah adalah stasiun pemantauan DKI 3 di Kota Jakarta Selatan. Tingginya konsentrasi polutan $\mathrm{PM}_{10}$ dapat menyebabkan gangguan pernafasan akut dan dapat menyebabkan penyakit paru-paru. Polutan $\mathrm{PM}_{10}$ adalah partikel debu yang berukuran $<10$ mikro yang masuk ke dalam tubuh dan tidak bisa di hambat oleh hidung. Polutan $\mathrm{PM}_{10}$ yang masuk ke dalam tubuh tertinggal dan menumpuk di dalam saluran pernafasan dan paru-paru. Maka dari itu pemantauan polutan $\mathrm{PM}_{10}$ perlu dilakukan.

\subsection{Pola Sebaran Kadar Polutan $\mathrm{SO}_{2}$ di Provinsi DKI Jakarta Tahun 2014-2018}

Pengambaran sebaran polutan $\mathrm{SO}_{2}$ di udara ambien menggunakan software Surfer 11, dengan menggunakan asumsi dari garis kontur.

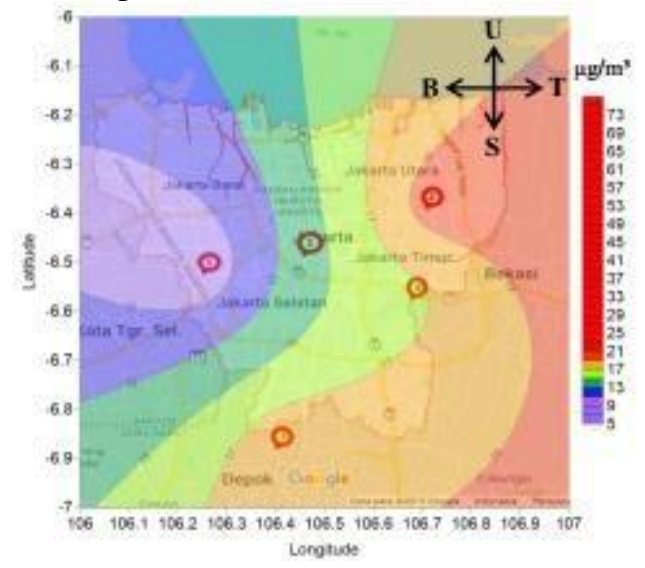

Gambar 7. Pola Sebaran $\mathrm{SO}_{2}$ di DKI Jakarta Tahun 2014

Daerah yang memiliki pola sebaran polutan $\mathrm{SO}_{2}$ tertinggi tahun 2014 dari stasiun pemantauan kualitas udara DKI 2 menyebar ke daerah Bekasi dengan kisaran konsentrasi > $20,00 \mu \mathrm{g} / \mathrm{m}^{3}$. Sedangkan daerah sebaran yang memiliki sebaran polutan dengan kadar rendah adalah DKI 1 menyebar ke DKI 5 di Kota Jakarta Barat memiliki kisaran kadar $<15,00 \mu \mathrm{g} / \mathrm{m}^{3}$.

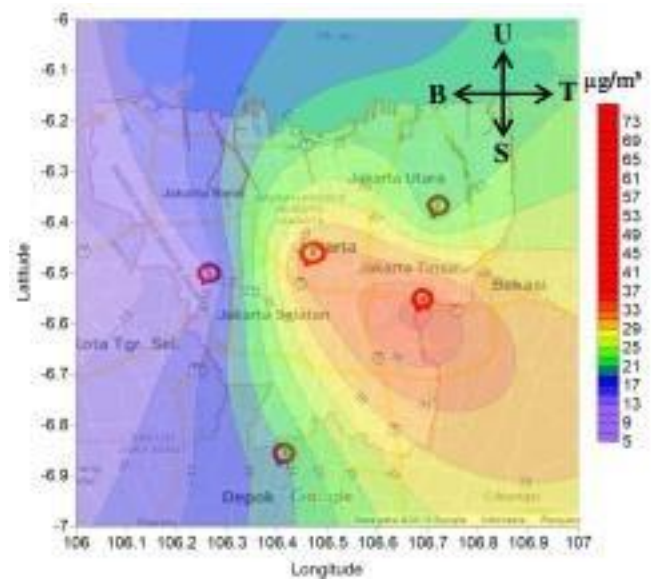

Gambar 8. Pola Sebaran $\mathrm{SO}_{2}$ di DKI Jakarta Tahun 2015 
Daerah yang memiliki pola sebaran polutan $\mathrm{SO}_{2}$ tertinggi tahun 2015 dari stasiun pemantauan kualitas udara DKI 1 menyebar ke DKI 4 dengan kisaran konsentrasi > 30,00 $\mu \mathrm{g} / \mathrm{m}^{3}$. Sedangkan daerah sebaran yang memiliki sebaran polutan dengan kadar rendah adalah DKI 2 dan DKI 3 menyebar ke DKI 5 di Kota Jakarta Barat memiliki kisaran kadar $<20,00$ $\mu \mathrm{g} / \mathrm{m}^{3}$.

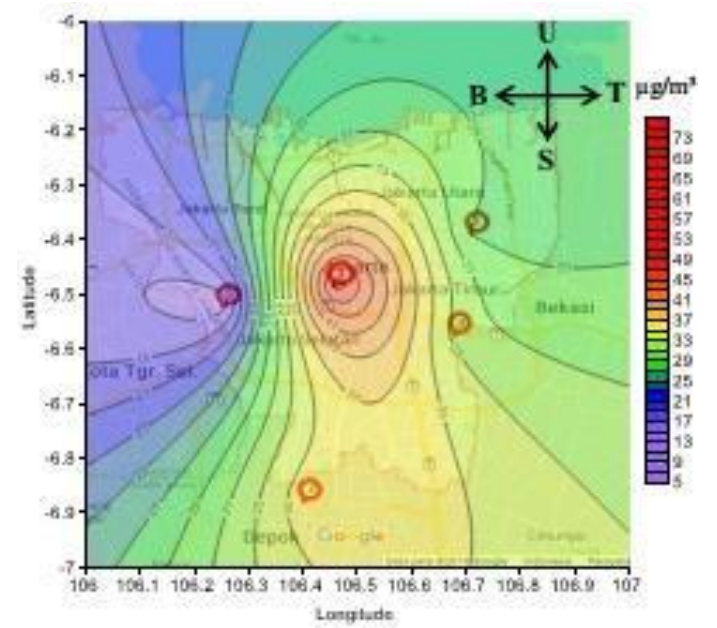

Gambar 9. Pola Sebaran $\mathrm{SO}_{2}$ di DKI Jakarta Tahun 2016

Daerah yang memiliki pola sebaran polutan $\mathrm{SO}_{2}$ tertinggi tahun 2016 dari stasiun pemantauan kualitas udara DKI 1 menyebar ke DKI 3 dengan kisaran konsentrasi > 30,00 $\mu \mathrm{g} / \mathrm{m}^{3}$. Sedangkan daerah sebaran yang memiliki sebaran polutan dengan kadar rendah adalah DKI 4 dan DKI 2 menyebar ke DKI 5 di Kota Jakarta Barat memiliki kisaran kadar $<25,00$ $\mu \mathrm{g} / \mathrm{m}^{3}$.

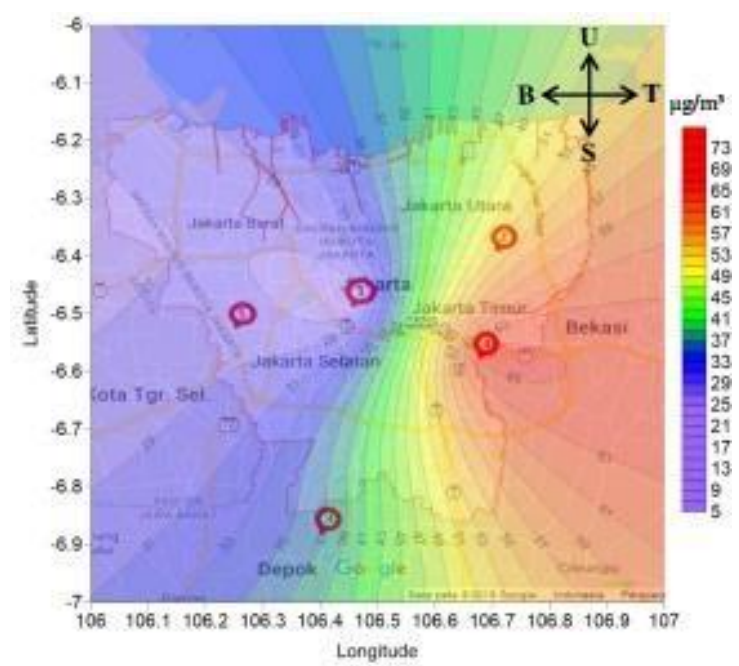

Gambar 10. Pola Sebaran $\mathrm{SO}_{2}$ di DKI Jakarta Tahun 2017

Daerah yang memiliki pola sebaran polutan $\mathrm{SO}_{2}$ tertinggi tahun 2017 dari stasiun pemantauan kualitas udara DKI 4 dan DKI 2 menyebar ke daerah Bekasi dengan kisaran konsentrasi $>40,00 \mu \mathrm{g} / \mathrm{m}^{3}$. Sedangkan daerah sebaran yang memiliki sebaran polutan dengan kadar rendah adalah DKI 1 dan DKI 3 menyebar ke DKI 5 di Kota Jakarta Barat memiliki kisaran kadar $<40,00 \mu \mathrm{g} / \mathrm{m}^{3}$. 


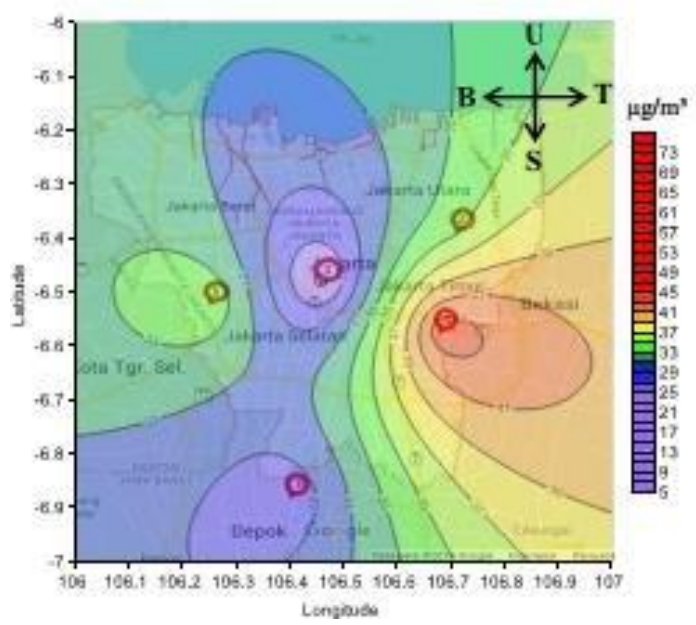

Gambar 11. Pola Sebaran $\mathrm{SO}_{2}$ di DKI Jakarta Tahun 2018

Daerah yang memiliki pola sebaran polutan $\mathrm{SO}_{2}$ tertinggi tahun 2017 dari stasiun pemantauan kualitas udara DKI 4 menyebar ke daerah Bekasi dengan kisaran konsentrasi > $35,00 \mu \mathrm{g} / \mathrm{m}^{3}$. Sedangkan daerah sebaran yang memiliki sebaran polutan dengan kadar rendah adalah DKI 1 menyebar ke DKI 3 di Kota Jakarta Selatan memiliki kisaran kadar $<30,00 \mu \mathrm{g} / \mathrm{m}^{3}$. Berdasarkan gambaran pola sebaran polutan $\mathrm{SO}_{2}$ di daerah DKI Jakarta tahun 2014-2018, pada tahun 2015, 2017 dan 2018 memiliki sebaran polutan $\mathrm{SO}_{2}$ tertinggi di stasiun pemantauan DKI 4 di Kota Jakarta Timur. Pada tahun 2014 dan 2016 sebaran polutan tertinggi terdapat di stasiun pemantauan DKI 1 di Kota Jakarta Pusat. Sedangkan untuk sebaran polutan terendah pada tahun 2014-2018 di stasiun pemantauan DKI 3 di Kota Jakarta Selatan dan DKI 5 di Kota Jakarta Barat. Polutan $\mathrm{SO}_{2}$ memiliki karakteristik gas berbau tajam dari unsur sulfur dan tidak berwarna. Polutan $\mathrm{SO}_{2}$ dihasilkan dari pembakaran senyawa- senyawa yang mengandung unsur sulfur. Senyawa $\mathrm{SO}_{2}$ masuk ke dalam tubuh manusia melalui saluran pernafasan, karna sifatnya yang asam maka senyawa $\mathrm{SO}_{2}$ dapat menyebabkan infeksi saluran pernafasan.

\subsection{Pola Sebaran Kadar Polutan CO di Provinsi DKI Jakarta Tahun 2014-2018}

Pengambaran sebaran polutan CO di udara ambien menggunakan software Surfer 11, dengan menggunakan asumsi dari garis kontur.

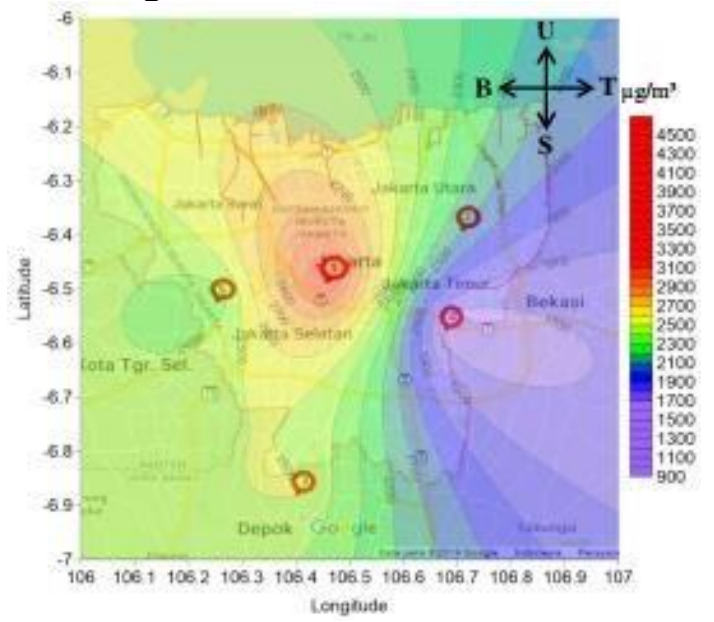

Gambar 12 Pola Sebaran CO di DKI Jakarta Tahun 2014

Daerah yang memiliki pola sebaran polutan CO tertinggi tahun 2014 dari stasiun pemantauan kualitas udara DKI 1 menyebar ke DKI 3 dan daeran Kota Jakarta Utara dengan kisaran konsentrasi $>2500,00 \mu \mathrm{g} / \mathrm{m}^{3}$. Sedangkan daerah yang memiliki sebaran polutan dengan 
kadar rendah adalah DKI 2 menyebar ke DKI 4 di Kota Jakarta Timur memiliki kisaran kadar $<2000,00 \mu \mathrm{g} / \mathrm{m}^{3}$.

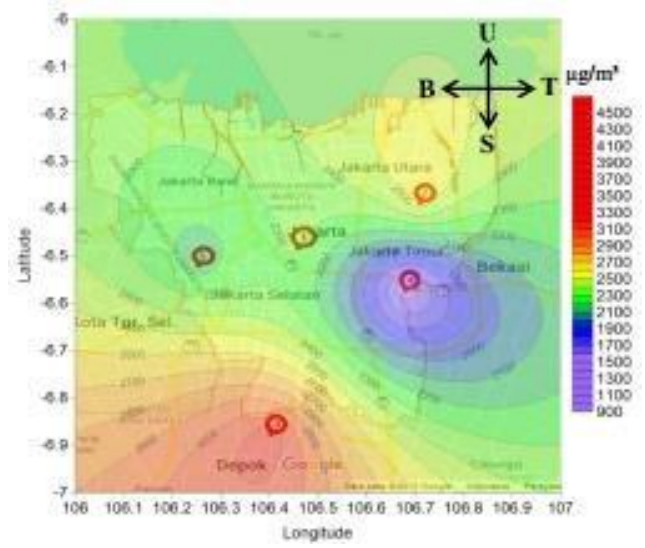

Gambar 13 Pola Sebaran CO di DKI Jakarta Tahun 2015

Daerah yang memiliki pola sebaran polutan CO tertinggi tahun 2015 adalah dari stasiun pemantauan kualitas udara DKI 3 ke daerah Depok dengan kisaran konsentrasi 2500,00 $\mu \mathrm{g} / \mathrm{m}^{3}$. Sedangkan daerah sebaran yang memiliki polutan dengan kadar rendah adalah DKI 4 di Kota Jakarta Timur memiliki kisaran kadar $<2200,00 \mu \mathrm{g} / \mathrm{m}^{3}$.

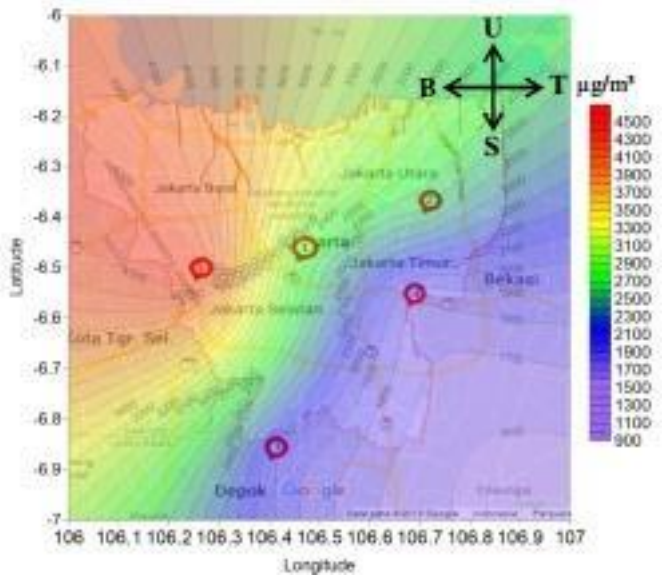

Gambar 14 Pola Sebaran CO di DKI Jakarta Tahun 2016

Daerah yang memiliki pola sebaran polutan CO tertinggi tahun 2016 adalah dari stasiun pemantauan kualitas udara DKI 5 menyebar ke Kota Jakarta Utara dengan kisaran konsentrasi $>2500,00 \mu \mathrm{g} / \mathrm{m}^{3}$. Sedangkan daerah sebaran yang memiliki polutan dengan kadar rendah adalah DKI 3 dan DKI 4 memiliki kisaran kadar $<18000,00 \mu \mathrm{g} / \mathrm{m}^{3}$.

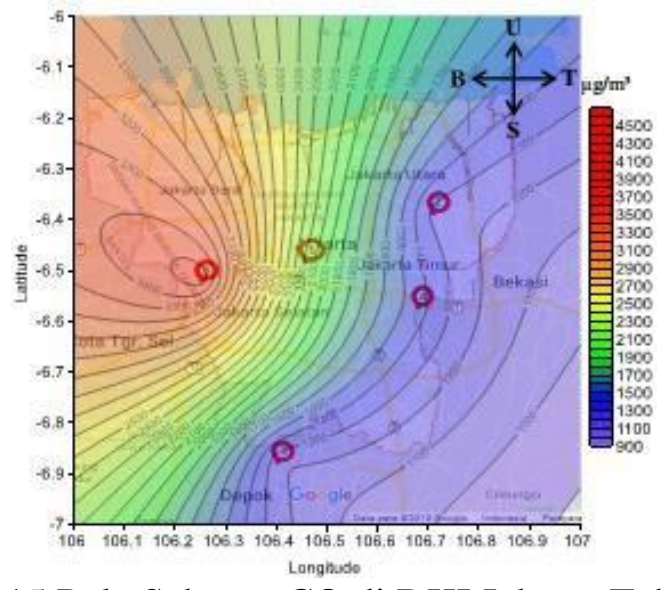

Gambar 15 Pola Sebaran CO di DKI Jakarta Tahun 2017 
Daerah yang memiliki pola sebaran polutan CO tertinggi tahun 2017 sama seperti tahun 2016 adalah dari stasiun pemantauan kualitas udara DKI 5 menyebar ke Kota Jakarta Utara dengan kisaran konsentrasi $>2500,00 \mu \mathrm{g} / \mathrm{m}^{3}$. Sedangkan daerah sebaran yang memiliki polutan dengan kadar rendah adalah DKI 3, DKI 2 dan DKI 4 memiliki kisaran kadar $<18000,00 \mu \mathrm{g} / \mathrm{m}^{3}$.

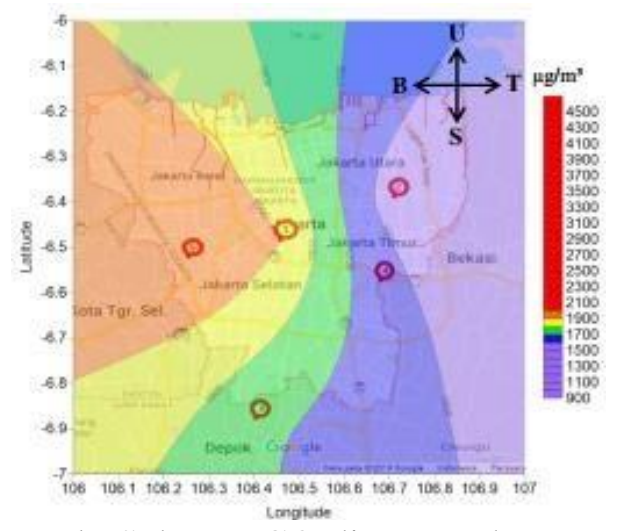

Gambar 16 Pola Sebaran CO di DKI Jakarta Tahun 2018

Daerah yang memiliki pola sebaran polutan CO tertinggi tahun 2018 sama seperti tahun 2016 adalah dari stasiun pemantauan kualitas udara DKI 5 menyebar ke Kota Tangerang Selatan dengan kisaran konsentrasi $>1900,00 \mu \mathrm{g} / \mathrm{m}^{3}$. Sedangkan daerah sebaran yang memiliki polutan dengan kadar rendah adalah DKI 2 dan DKI 4 memiliki kisaran kadar $<16000,00$ $\mu \mathrm{g} / \mathrm{m}^{3}$.

Dilihat dari pola sebaran polutan CO di DKI Jakarta dari tahun 2014-2018, pada tiga tahun terakhir sebaran polutan CO dengan kadar tertinggi terdapat di stasiun pemantauan udara DKI 5 yang menyebar ke Kota Jakarta Utara dan Kota Tangerang Selatan. Namun pada tahun 2014 kadar tertinggi berada di stasiun pemantauan DKI 1 dan pada tahun 2015 berada di DKI 3. Sedangkan untuk daerah sebaran polutan CO terendah setiap tahun dalam lima tahun terakhir adalah di stasiun pemantauan udara DKI 4 di Kota Jakarta Timur.

Polutan CO dihasilkan dari proses pembakaran yang kurang sempurna, karna jika sempurna akan membentuk $\mathrm{CO}_{2}$. CO bisa bersumber dari industri, kendaraan bermotor maupun naktivitas manusia seperti pembakaran sampah. Gas CO mempunyai potensi bersifat racun yang berbahaya karena mampu membentuk ikatan yang kuat dengan pigmen darah yaitu hemoglobin. Proses ikatan CO dengan hemoglobin lebih cepat daripada ikatan oksigen dengan hemoglobin, maka hemoglobin akan berikatan dengan $\mathrm{CO}$ terlebih dahulu daripada dengan oksigen.

\subsection{Pola Sebaran Kadar Polutan O3 di Provinsi DKI Jakarta Tahun 2014-2018}

Pengambaran sebaran polutan $\mathrm{O}_{3}$ di udara ambien menggunakan software Surfer 11, dengan menggunakan asumsi dari garis kontur.

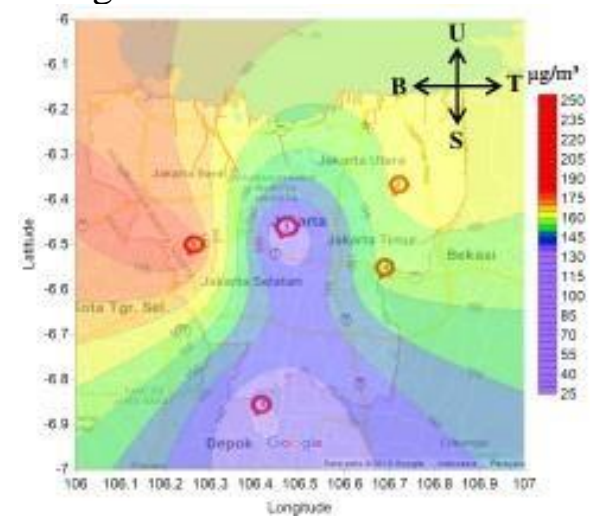

Gambar 17 Pola Sebaran O O $_{3}$ di DKI Jakarta Tahun 2014 
Daerah yang memiliki pola sebaran polutan $\mathrm{O}_{3}$ tertinggi tahun 2014 adalah dari stasiun pemantauan kualitas udara DKI 5 ke Kota Tangerang Selatan dengan kisaran konsentrasi > $170,00 \mu \mathrm{g} / \mathrm{m}^{3}$. Sedangkan daerah sebaran yang memiliki polutan dengan kadar rendah adalah DKI 1 dan DKI 3 memiliki kisaran kadar $<150,00 \mu \mathrm{g} / \mathrm{m}^{3}$.

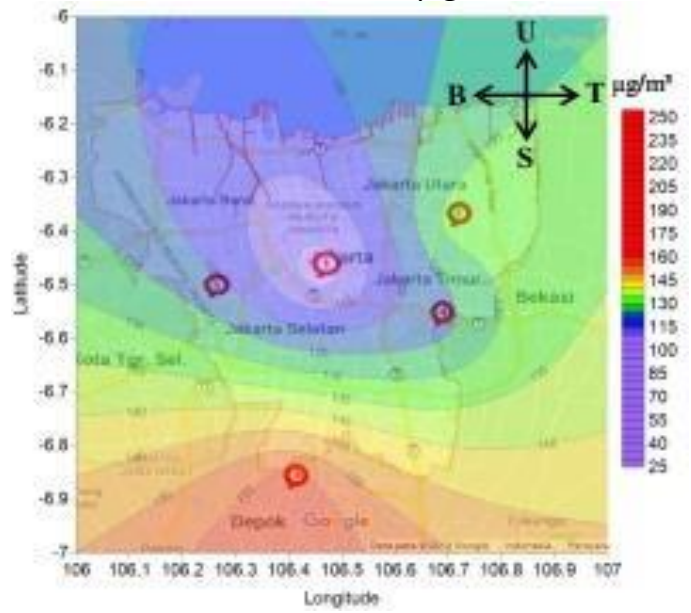

Gambar 18 Pola Sebaran O3 di DKI Jakarta Tahun 2015

Daerah yang memiliki pola sebaran polutan $\mathrm{O}_{3}$ tertinggi tahun 2015 adalah dari stasiun pemantauan kualitas udara DKI 3 ke Kota Depok dengan kisaran konsentrasi $>150,00 \mu \mathrm{g} / \mathrm{m}^{3}$. Sedangkan daerah sebaran yang memiliki polutan dengan kadar rendah adalah DKI 4, DKI 1 dan DKI 5 menyebar ke Kota Jakarta Utara memiliki kisaran kadar $<125,00 \mu \mathrm{g} / \mathrm{m}^{3}$.

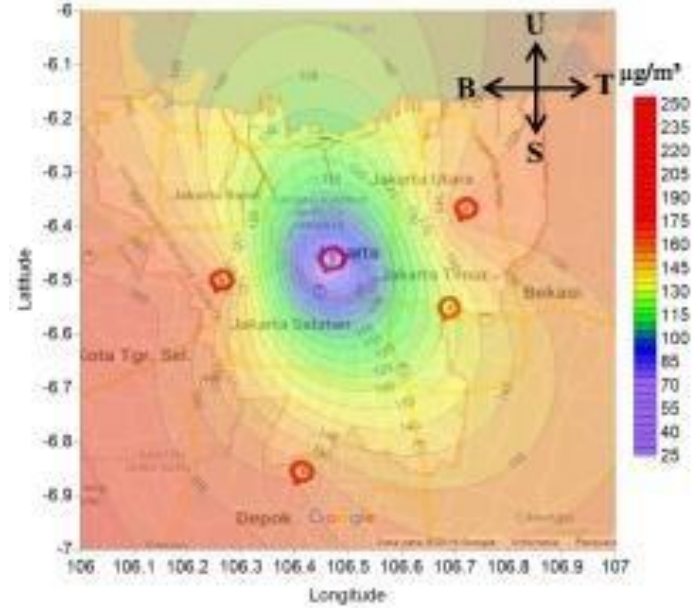

Gambar 19 Pola Sebaran $\mathrm{O}_{3}$ di DKI Jakarta Tahun 2016

Daerah yang memiliki pola sebaran polutan $\mathrm{O}_{3}$ tertinggi tahun 2016 adalah dari stasiun pemantauan kualitas udara DKI 2, DKI 3 dan DKI 5 dengan kisaran konsentrasi > 150,00 $\mu \mathrm{g} / \mathrm{m}^{3}$. Sedangkan daerah sebaran yang memiliki polutan dengan kadar rendah adalah DKI 1 Kota Jakarta Pusat memiliki kisaran kadar $<110,00 \mu \mathrm{g} / \mathrm{m}^{3}$. 


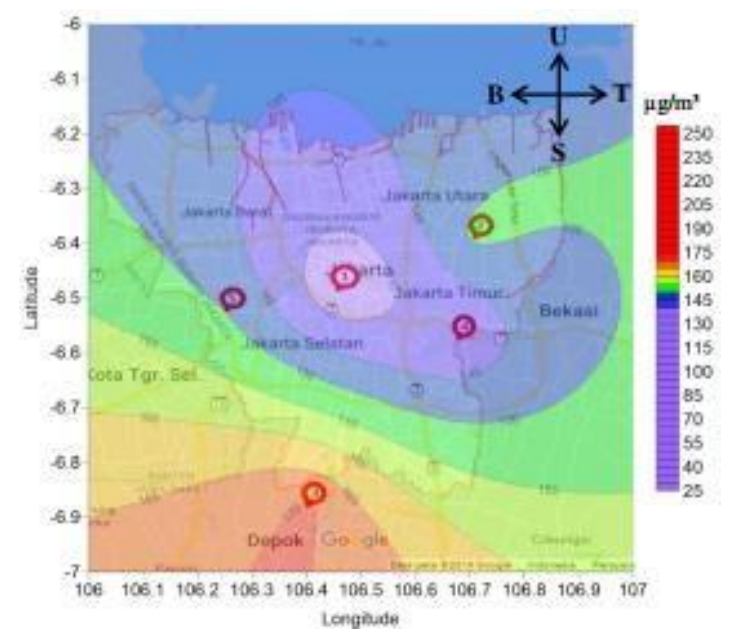

Gambar 20 Pola Sebaran $\mathrm{O}_{3}$ di DKI Jakarta Tahun 2017

Daerah yang memiliki pola sebaran polutan $\mathrm{O}_{3}$ tertinggi tahun 2017 adalah dari stasiun pemantauan kualitas udara DKI 3 dengan kisaran konsentrasi $>160,00 \mu \mathrm{g} / \mathrm{m}^{3}$. Sedangkan daerah sebaran yang memiliki polutan dengan kadar rendah adalah DKI 1, DKI 4 dan DKI 5 ke Kota Jakarta Barat dan Jakarta Utara memiliki kisaran kadar $<145,00 \mu \mathrm{g} / \mathrm{m}^{3}$.

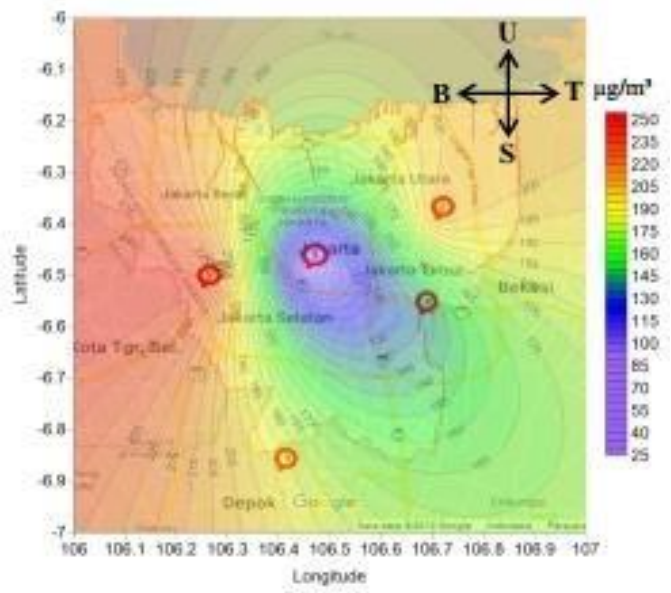

Gambar 21 Pola Sebaran $\mathrm{O}_{3}$ di DKI Jakarta Tahun 2018

Daerah yang memiliki pola sebaran polutan $\mathrm{O}_{3}$ tertinggi tahun 2018 adalah dari stasiun pemantauan kualitas udara DKI 5 ke daerah Kota Tangerang Selatan dengan kisaran konsentrasi $>200,00 \mu \mathrm{g} / \mathrm{m}^{3}$. Sedangkan daerah sebaran yang memiliki polutan dengan kadar rendah adalah DKI 1 Kota Jakarta Pusat memiliki kisaran kadar $<140,00 \mu \mathrm{g} / \mathrm{m}^{3}$.

Dari hasil gambaran pola sebaran polutan $\mathrm{O}_{3}$ di DKI Jakarta tahun 2014-2018, maka pada tahun 2016 paling buruk karna di DKI 4 Kota Jakarta Timur, DKI 3 Kota Jakarta Selatan dan DKI 5 Kota Jakarta Barat memiliki sebaran kadar yang tinggi. Sedangkan pada tahun 2014 and 2018 sebaran kadar tertinggi terdapat di DKI 5 Kota Jakarta Barat, tahun 2015 dan tahun 2017 sebaran kadar polutan $\mathrm{O}_{3}$ tertinggi terdapat di DKI 3 Kota Jakarta Selatan. Sedangkan DKI 1 Kota Jakarta Pusat selalu memiliki sebaran kadar polutan terendah dari tahun 2014-2018.

Polutan $\mathrm{O}_{3}$ pada kadar tinggi bisa berakibat fatal pada saluran pernafasan manusia. Kadar $\mathrm{O}_{3}$ yang tinggi yang masuk melalui saluran pernafasan manusia akan mengakibatkan infeksi pada saluran pernafasan. Udara ambien dengan kadar tinggi juga bisa mengakibatkan iritasi pada mata. 


\subsection{Pola Sebaran Kadar Polutan $\mathrm{NO}_{2}$ di Provinsi DKI Jakarta Tahun 2014-2018}

Pengambaran sebaran polutan $\mathrm{NO}_{2}$ di udara ambien menggunakan software Surfer 11, dengan menggunakan asumsi dari garis kontur.

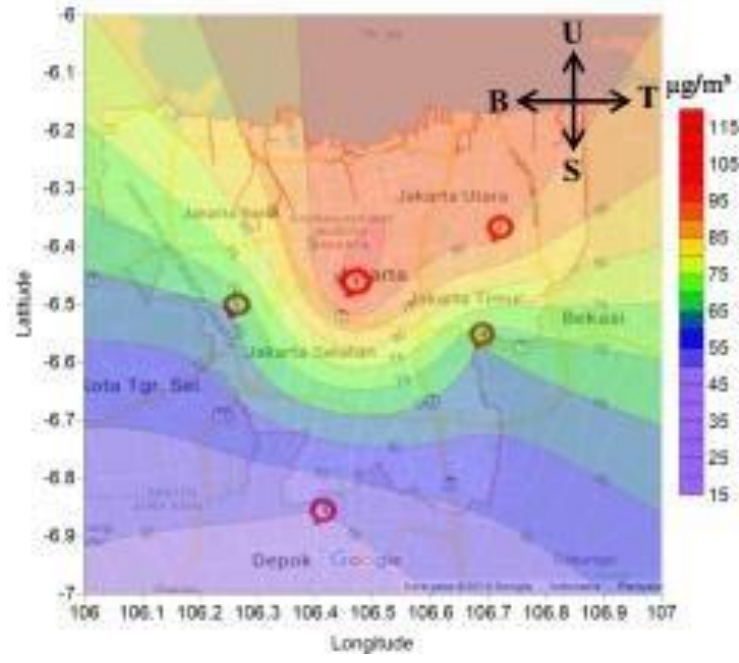

Gambar 22 Pola Sebaran $\mathrm{NO}_{2}$ di DKI Jakarta Tahun 2014

Daerah yang memiliki pola sebaran polutan $\mathrm{NO}_{2}$ tertinggi tahun 2014 adalah dari stasiun pemantauan kualitas udara DKI 1 dan DKI 2 ke daerah Laut Jawa dengan kisaran konsentrasi $>90,00 \mu \mathrm{g} / \mathrm{m}^{3}$. Sedangkan daerah sebaran yang memiliki polutan dengan kadar rendah adalah DKI 3 Kota Jakarta Selatan memiliki kisaran kadar $<60,00 \mu \mathrm{g} / \mathrm{m}^{3}$.

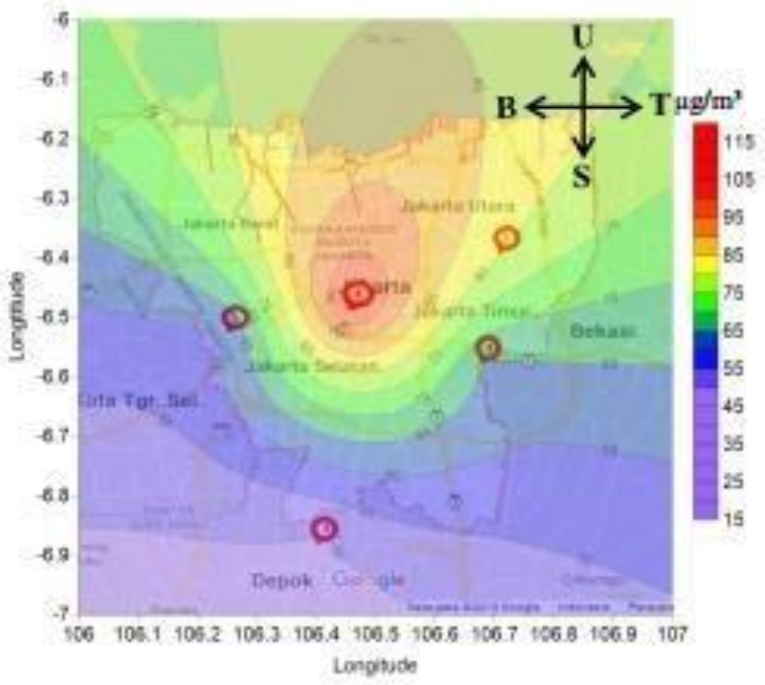

Gambar 23 Pola Sebaran $\mathrm{NO}_{2}$ di DKI Jakarta Tahun 2015

Daerah yang memiliki pola sebaran polutan $\mathrm{NO}_{2}$ tertinggi tahun 2015 sama seperti tahun 2014 adalah dari stasiun pemantauan kualitas udara DKI 1 ke daerah Kota Jakarta Utara dan Laut Jawa dengan kisaran konsentrasi $>80,00 \mu \mathrm{g} / \mathrm{m}^{3}$. Sedangkan daerah sebaran yang memiliki polutan dengan kadar rendah adalah DKI 3 Kota Jakarta Selatan memiliki kisaran kadar $<60,00$ $\mu \mathrm{g} / \mathrm{m}^{3}$. 


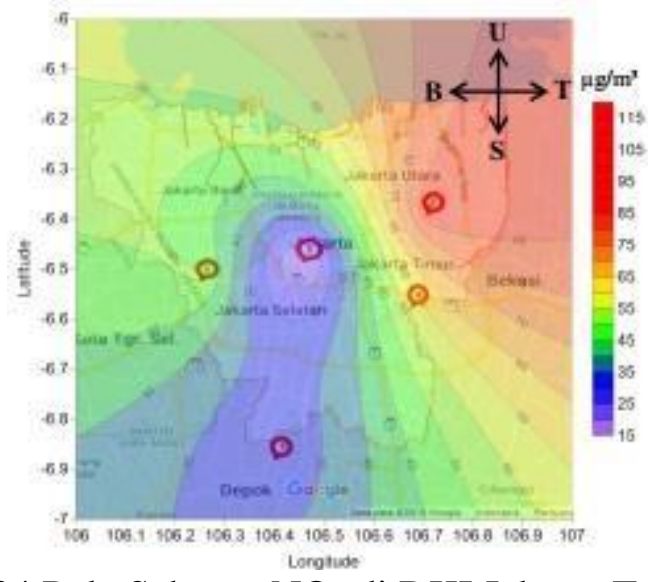

Gambar 24 Pola Sebaran $\mathrm{NO}_{2}$ di DKI Jakarta Tahun 2016

Daerah yang memiliki pola sebaran polutan $\mathrm{NO}_{2}$ tertinggi tahun 2016 adalah dari stasiun pemantauan kualitas udara DKI 2 ke daerah Kota Bekasi dengan kisaran konsentrasi > 80,00 $\mu \mathrm{g} / \mathrm{m}^{3}$. Sedangkan daerah sebaran yang memiliki polutan dengan kadar rendah adalah DKI 1 Kota Jakarta Pusat dan DKI 3 Kota Jakarta Selatan memiliki kisaran kadar $<35,00 \mu \mathrm{g} / \mathrm{m}^{3}$.

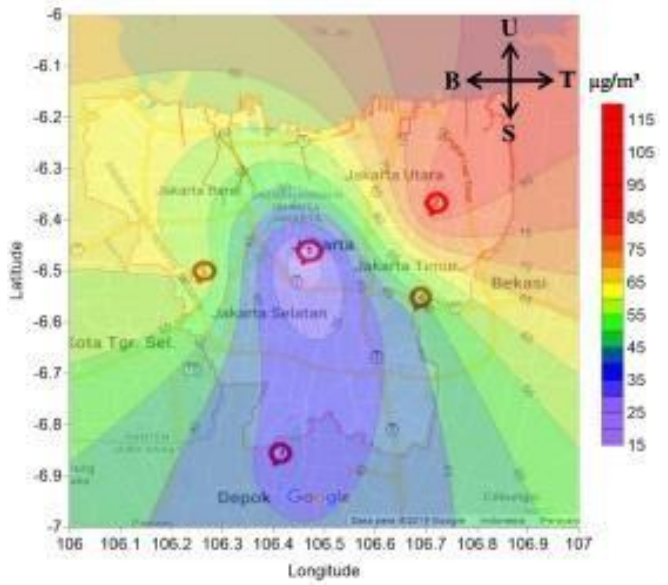

Gambar 25 Pola Sebaran $\mathrm{NO}_{2}$ di DKI Jakarta Tahun 2017

Daerah yang memiliki pola sebaran polutan $\mathrm{NO}_{2}$ tertinggi tahun 2017 sama seperti tahun 2016 adalah dari stasiun pemantauan kualitas udara DKI 2 ke daerah Kota Bekasi dengan kisaran konsentrasi $>75,00 \mu \mathrm{g} / \mathrm{m}^{3}$. Sedangkan daerah sebaran yang memiliki polutan dengan kadar rendah adalah DKI 1 Kota Jakarta Pusat dan DKI 3 Kota Jakarta Selatan memiliki kisaran $\operatorname{kadar}<45,00 \mu \mathrm{g} / \mathrm{m}^{3}$.

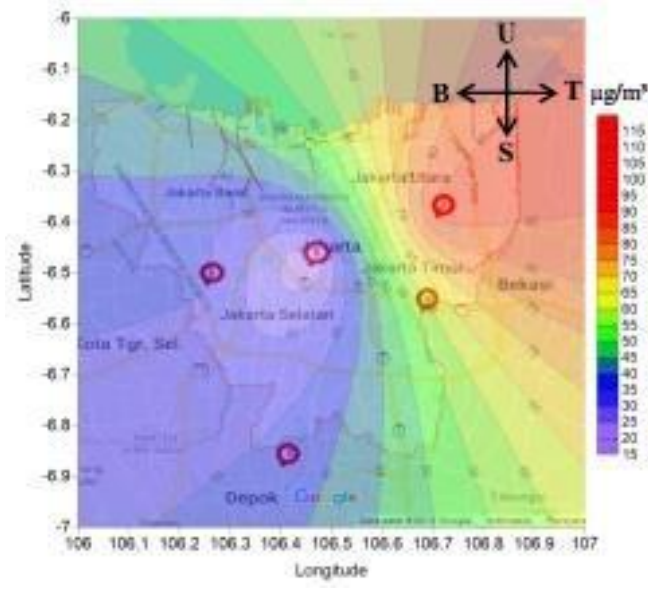

Gambar 26 Pola Sebaran NO 2 di DKI Jakarta Tahun 2018 
Daerah yang memiliki pola sebaran polutan $\mathrm{NO}_{2}$ tertinggi tahun 2018 sama seperti tahun 2017 adalah dari stasiun pemantauan kualitas udara DKI 2 ke daerah Kota Bekasi dengan kisaran konsentrasi $>80,00 \mu \mathrm{g} / \mathrm{m}^{3}$. Sedangkan daerah sebaran yang memiliki polutan dengan kadar rendah adalah DKI 1 Kota Jakarta Pusat, DKI 5 Kota Jakarta Barat dan DKI 3 Kota Jakarta Selatan memiliki kisaran kadar $<40,00 \mu \mathrm{g} / \mathrm{m}^{3}$.

Dari gambaran pola sebaran polutan $\mathrm{NO}_{2}$ di DKI Jakarta tahun 2014-2018, pada tahun 2016-2018 di stasiun pemantauan DKI 2 Kota Jakarta Utara memiliki kadar yang tertinggi. Namun pada tahun 2014-2015 kota yang memiliki sebaran kadar tertinggi adalah Kota Jakarta Pusat dengan stasiun pemantauan DKI 1. Sedangkan untuk sebaran dengan kadar rendah terdapat di DKI 3 Kota Jakarta Selatan tahun 2014-2018.

Seperti halnya polutan $\mathrm{SO}_{2}$, polutan $\mathrm{NO}_{2}$ juga berbahaya bagi saluran pernafasan manusia dapat menyebabkan infeksi pada kadar tinggi. Apabila kadar polutan $\mathrm{NO}_{2}$ tinggi di udara maka apabila turun hujan dapat bereaksi dengan air hujan membentuk $\mathrm{HNO}_{2}$ atau $\mathrm{HNO}_{3}$ yang merupakan senyawa asam. Maka terjadilah hujan asam yang sangat berbahaya bagi pertumbuhan tanaman dan hewan.

\section{Kesimpulan}

Dari hasil dan pembahasan di atas maka didapatkan kesimpulan sebagai berikut:

1. Dari stasiun pemantauan kualitas udara di dapatkan hasil kadar bahwa polutan $\mathrm{PM}_{10}$ maksimum range $158,00-206,00 \mu \mathrm{g} / \mathrm{m}^{3}$ telah melewati NAB sebesar $150,00 \mu \mathrm{g} / \mathrm{m}^{3} \mathrm{di}$ DKI Jakarta. Pada polutan $\mathrm{O}_{3}$ yang diukur menghasilkan kadar maksimum pada range 249,00- 456,10 $\mu \mathrm{g} / \mathrm{m}^{3}$ yang melewati NAB sebesar $235,00 \mu \mathrm{g} / \mathrm{m}^{3}$ di DKI Jakarta. Sedangkan kadar polutan $\mathrm{SO}_{2}, \mathrm{CO}$ dan $\mathrm{NO}_{2}$ kadar aman di bawah NAB sebesar berurutan $365,00 \mu \mathrm{g} / \mathrm{m}^{3}, 30.000 \mu \mathrm{g} / \mathrm{m}^{3}$ dan $400,00 \mu \mathrm{g} / \mathrm{m}^{3}$ di DKI Jakarta.

2. Kualitas udara parameter $\mathrm{CO}$ tidak dapat dihitung karena kadarnya tinggi berdasarkan tabel nilai ISPU standar CO tertinggi untuk dihitung $57,5 \mu \mathrm{g} / \mathrm{m}^{3}$ parameter kritis yang dijadikan penentu kategori ISPU mayoritas adalah $\mathrm{O}_{3}$ dan $\mathrm{PM}_{10}$ di lima kota di DKI Jakarta. Kota Jakarta Pusat dengan hasil kualitas udara paling buruk adalah tahun 2017 dengan 28 hari tidak sehat, sedangkan kualitas paling baik tahun 2015 dengan nol hari tidak sehat. Kota Jakarta Utara tahun 2018 paling buruk dengan 11 hari sangat tidak sehat dan 117 tidak sehat, sedangkan kualitas udara paling baik tahun 2015 dengan 15 hari tidak sehat. Kota Jakarta Selatan kualitas paling buruk tahun 2018 dengan 81 hari tidak sehat, sedangkan kualitas udara yang paling baik tahun 2014 dengan 20 hari tidak sehat. Kota Jakarta Timur kualitas paling buruk tahun 2014 dengan 3 hari sangat tidak sehat dan 19 hari tidak sehat, sedangkan kualitas udara yang paling baik tahun 2018 dengan 11 hari tidak sehat. Kota Jakarta Barat kualitas yang buruk pada tahun 2018 dengan 19 hari sangat tidak sehat dan 166 hari tidak sehat, sedangkan kualitas udara yang paling baik tahun 2015 dengan 7 hari tidak sehat.

3. Berdasarkan pola sebaran kadar polutan untuk $\mathrm{PM}_{10}$ dan $\mathrm{SO}_{2}$ dari tahun 2014- 2018 mengalami perbaikan dikarenakan meningkatnya zonasi daerah yang memiliki kadar polutan rendah masing- masing $<40,00 \mu \mathrm{g} / \mathrm{m}^{3}$ dan $<30,00 \mu \mathrm{g} / \mathrm{m}^{3}$. Salah satu faktornya adalah menurunnya jumlah kendaraan di DKI Jakarta dan meningkatnya teknologi pada kendaraan agar ramah lingkungan seperti mengganti transjakarta menjadi standar mesin Uni- Eropa IV-V dari Uni-Eropa II, ISS (Idling Stop System) pada kendaraan motor dan teknologi yang sudah ada namun masih jarang di manfaatkan yaitu subtitusi BBM menjadi BBG. Dilihat dari pola sebaran kadar polutan $\mathrm{CO}$ dan $\mathrm{NO}_{2}$ dari tahun 20142018 tidak mengalami peningkatan kualitas udara namun mengalami perubahan zona daerah pada tahun 2014 Kota Jakarta Pusat yang memiliki kadar polutan tinggi namun pada tahun 2015-2018 berubah menjadi daerah Kota Jakarta Barat dikarenakan 
banyaknya pembangunan gedung pemerintahan dan mall-mall besar. Khusus pola sebaran kadar polutan $\mathrm{O}_{3}$ menunjukan adanya penurunan kualitas udara di DKI Jakarta pada tahun 2016 dan 2018 dilihat dari semakin banyaknnya zona daerah yang memiliki kadar polutan tinggi $>150,00 \mu \mathrm{g} / \mathrm{m}^{3}$ yang bisa mengakibatkan infeksi pada saluran pernafasan dan iritasi pada mata.

\section{Daftar Pustaka}

Apriawati, Eka dkk. (2017). Kajian Indeks Standar Polusi Udara (ISPU) Nitrogen Dioksida $\left(\mathrm{NO}_{2}\right)$ di Tiga Lokasi Kota Bandar Lampung. Jurnal Ilmiah Analytical and Environmental Chemistry. Volume 2, No. 01, E- ISSN 2540-8267, Bandar Lampung.

BADAN PUSAT STATISTIK. (2015). Pertumbuhan Produksi Industri Manufaktur Provinsi DKI Jakarta 2015. BPS, Jakarta.

BADAN PUSAT STATISTIK. (2017). Pertumbuhan Produksi Industri Manufaktur Provinsi DKI Jakarta 2017. BPS, Jakarta.

BADAN PUSAT STATISTIK. (2018). Provinsi DKI Jakarta Dalam Angka 2018. BPS, Jakarta.

BADAN PUSAT STATISTIK. (2018). Statistik Transportasi DKI Jakarta. BPS, Jakarta.

Badan Pengelolaan Lingkungan Hidup Daerah. (2015). Status Lingkungan Hidup Daerah Provinsi DKI Jakarta. BBPLHD, Jakarta.

Dinas Lingkungan Hidup (DLH) DKI Jakarta. (2019). Indeks Standar Pencemar Udara. Jakarta.

Fernando, Julius Alex. (2017). Identifikasi Konstribusi Pencemaran PM10 Menggunakan Metode Reseptor Chemical Mass Balance (CMB). Jurnal Ilmiah Vol. 6 No. 2. Universitas Diponegoro, Semarang.

Ikhtiar, Muhammad. (2017). Analisis Kualitas Lingkungan. SIGn, Makasar.

Irianto, Ketut. (2015). Pencemaran Lingkungan. Universitas Warmadewa, Bali.

Kamal, Nahlah Mustafa. (2015). Studi Tingkat Kualitas Udara Pada Kawasan Mall Panakukang Di Makasar. Universitas Hsanudin, Makasar.

KEPUTUSAN BAPEDAL No.107. (1997). Perhitungan Dan Pelaporan Serta Informasi Indeks Standar Pencemar Udara. KEPBAPEDAL, Jakarta.

Keputusan Menteri Negara Lingkungan Hidup. (1997). Indeks Standar Pencemar Udara. KEPMENLH, Jakarta.

PERATURAN PEMERINTAH. (1999). Pengendalian Pencemaran Udara PP RI No.41/1999, Jakarta.

PERMENLHK. (2016). Pedoman Nomenklatur Perangkat Daerah Provinsi Dan Kabupaten/Kota Yang Melaksanakan Urusan Pemerintahan Bidang Lingkungan Hidup Dan Urusan Pemerintahan Bidang Kehutanan. MENLHKRI.

Prabhandhari, Diah. (2014). Analisis Status Kualitas Udara Lima Kota Metropolitan Di Indonesia. Skripsi Program Studi Teknik Sipil Dan Lingkungan. Institut Pertanian Bogor, Bogor.

Rualinda, Yeni dkk. (2014). Analisis Kualitas Udara Ambien Kota Padang Akibat Pencemar Particulate Matter $10 \mu \mathrm{m}$ (PM10). Jurnal Ilmiah Vol. 21 No 2 ISSN 0854-8471, Padang.

Sutriyani, Yani. (2014). Pencemaran Lingkungan. Ciputat, Tangerang. 